\title{
Short-term Leaf Responses of Nicotiana tabacum 'Bel-W3' to Ozone under the Environmental Conditions of São Paulo, SE - Brazil
}

\author{
Silvia Ribeiro de Souza, Silvia Maria Romano Sant'Anna, Mirian Cilene Spasiani Rinaldi \\ and Marisa Domingos* \\ Seção de Ecologia; Instituto de Botânica; C. P.: 3005; 01061- 970; São Paulo - SP-Brasil
}

\begin{abstract}
The present study aimed to study if the intensity and precocity of short-term leaf responses of Nicotiana tabacum 'Bel-W3' depended on the daily atmospheric levels of ozone and/or daily meteorological conditions in a State Park located in the city of São Paulo, SE Brazil. From 16 September to 14 October 2002, three lots of six potted plants were exposed for fourteen days. Leaf necrosis, atmospheric ozone concentrations and meteorological parameters were daily measured. The average percentage of leaf necrosis ranged from 5\% to 20\%. A 4th degree polynomial model was proposed to explain daily progress of leaf necrosis on plants. The average ozone levels were increased from morning (1.3-39.2 ppbv) to the midday (1.6-52.0 ppbv) and decreased in the evening (0.5-39.9 ppbv). Daily pattern of accumulated percentage of leaf necrosis was not strictly related to ozone, but was influenced by the meteorological conditions and stage of development of leaves.
\end{abstract}

Key words: Leaf necrosis, N. tabacum Bel-W3, ozone, meteorological parameters

\section{INTRODUCTION}

Air pollution is a serious problem in many heavily populated and industrialized areas in the world. It affects vegetation, human health and also materials. Photochemical oxidants, mainly ozone, are considered to have the greatest impact on vegetation and humans amongst the air pollutants of regional distribution (Treshow and Kanderson, 1991; Grünhage and Jäger, 2003). These compounds are produced by photochemical reactions when primary precursors such as nitrogen oxide and organic compounds are present together, which in turn have been increasingly emitted by industries and motor vehicles. Furthermore, these reactions, besides being intensified by high temperature and light intensities, also yield different compounds.

Harmful effects of ozone, such as chlorotic and necrotic injuries, have frequently been observed on sensitive plants (Horsman, 1981; Franzaring et al., 2000; Sandermann, 2000; Orendovici et al., 2003). These visible and typical symptoms have long been considered for risk prognosis in biomonitoring programs (Manning and Feder, 1980; Krupa and Manning, 1988). The cultivar Bel-W3 of Nicotiana tabacum L. is the best defined and described, and the most widely used

\footnotetext{
* Author for correspondence: mmingos@ superig.com.br
} 
sensitive bioindicator for ambient ozone, especially in the United States and Europe (Krupa and Manning, 1988; Heggestad, 1991; Krupa et al., 1993; Klumpp et al., 2002; Vergé et al., 2002). However, sensitive bioindicator plants of ozone exposed in the environment interact not only with the pollutant but also with biotic and abiotic factors that may affect their performance by visible responses. This must be recognized and taken into account in the interpretation of results from biomonitoring studies (Krupa and Manning, 1988).

The air quality at the metropolitan area of São Paulo (SPM), the largest urbanized and industrialized region in Brazil, has been rarely characterized by means of sensitive bioindicator plants (Klumpp et al., 1994; Domingos et al., 2002), although this is theoretically an useful way to spread the area of air quality monitoring in the region. However, reliable results would only be reached by measuring the standardized visible responses of bioindicator plants under regional environmental conditions.

The diversification of emission sources at the SPM, among them vehicles, industrial processes, waste burnings and fuel storage, creates zones with different species and concentrations of air pollutants (Souza et al., 1999). Besides, the SPM is surrounded by mountains ranging from 650 to $1200 \mathrm{~m}$ high, which facilitates the trapping of dust and air pollutants in the inversion layer, providing ideal conditions to occur photochemical reactions. Previous long-term field exposures of $N$. tabacum 'Bel-W3' in many locations of the SPM revealed that significant linear relations between percentage of leaf area affected by necroses and tropospheric ozone levels, an ideal situation for biomonitoring purposes, were rarely reached. These results made to suppose that visible responses of this tobacco depended on the daily atmospheric situation during the period of exposure, which in turn could interfere on the ozone diffusion through stomata and then on the efficiency of biomonitoring programs in the region.

To test this hypothesis, the present study aimed at studying whether the intensity and precocity of short-term leaf responses of $N$. tabacum Bel-W3 depended on the daily atmospheric levels of ozone and/or on daily meteorological conditions. Hence, the plants of this species were exposed to a heavily polluted situation observed in an urbanized site of São Paulo, during a short period of time, along with the visible leaf responses, the tropospheric levels of ozone and the meteorological conditions were daily evaluated. The experimental design adopted also permitted to verify whether the developmental stage of leaves could interfere on the daily relations between visible responses of plants and ozone concentrations.

\section{MATERIALS AND METHODS}

\section{Exposure site and sampling}

The experimental site was located at the Institute of Botany (IBt), in a State Park located in the South region of the city of São Paulo - SE Brazil, $\left(23^{\circ} 45^{\prime}-23^{\circ} 55^{\prime} \mathrm{S}\right), 800 \mathrm{~m}$ above sea level and approximately $3 \mathrm{Km}$ far from a major highway with frequently dense vehicular traffic. The topography is rather complex and the air flow is strongly influenced by the local conditions. This site can be considered potentially impacted by different types of pollution sources. The precursors of the ozone in the region seem to come predominantly from biogenic emissions from the fragment of forest protected by the State Park and from vehicular emissions (Souza and Carvalho, 2001; Montero et al., 2002). In the springtime, from 16 September to 14 October 2002, air sampling and tobacco Bel-W3 exposures were done. During this period, the sampling air was daily performed in the morning (8:00 - 9:00 a.m.), midday (12:00 - 1:00 p.m.) and evening (4:00-5:00 pm) periods. A total of 60 air samples were taken with $95 \%$ above the lower limit of detection established by the methods of analysis. During this period, three lots of six potted plants were exposed during fourteen days each, so that a new lot of plants was introduced every week. The plant cultivation and field exposure system were those recommended by VDI (2000). The atmospheric air collections and bioindicator plant exposures were concomitantly performed in a greenhouse with filtered air, settled next to the mentioned sampling system, representing the reference situation. In this environment, the chemicals were below the analytical detection limits and the plants never showed leaf necroses. The tobacco plant cultivation was also performed in this greenhouse. Meteorological parameters, such as temperature (av. $25^{\circ} \mathrm{C}$ ), relative humidity (av. 68.5\%) and solar global radiation (av. $380 \mathrm{MJ} / \mathrm{m} 2$ ) were recorded during all the sampling period by a meteorological station belonged to the Geophysical and 
Astronomic Institute, University of São Paulo, also located at the State Park.

\section{Analytical procedures and assessment of leaf necrosis}

Ozone $\left(\mathrm{O}_{3}\right)$ was sampled using the aqueous scrubber technique. The sampled air passed through a filter to remove the aerosol particles and then to an adsorbent solution. Air was drawn through a midget impinger containing $10 \mathrm{~mL}$ of aqueous solution of $1 \%$ potassium iodide in a neutral buffer ( $\mathrm{pH}$ 6.8), composed of 0.1 mol. $\mathrm{L}^{-1}$ disodium hydrogen phosphate and $0.1 \mathrm{~mol} . \mathrm{L}^{-1}$ potassium dihydrogen phosphate (Saltzman, 1972). Air samples were taken during 30 minutes at a flow rate of $2 \mathrm{~L} \cdot \mathrm{min}^{-1}$. At least three blank samples were prepared in each sampling day. After sampling, ozone was determined spectrophotometrically by measuring absorption at $352 \mathrm{~nm}$ (Shimadzu UV-visible 160A). The accumulated percentages of leaf area affected by typical necroses (interveinal portions of dead leaf tissues, grayish to brownish, with varied sizes and shapes) were determined everyday in the forth to sixth older leaves of all lots of plants, according to the protocol established by VDI (2000). The results were expressed in average accumulated percentage of leaf area affected by necroses.

\section{Statistical analysis}

Differences in ozone concentrations during the day were identified by the analysis of variance followed by pairwise comparison test. Pearson correlations showed the relations among the abiotic variables. Regression curves fitted the progress of leaf area occupied by necroses during each exposure. Their significance was determined in all cases by analysis of variance followed by the calculation of the least significant difference $(\mathrm{P}<$ $0.05)$.

\section{RESULTS}

The mixing ratio ranges of ozone during the sampling period are showed in Fig. 1. The values ranged from 1.34 to $39.2 \mathrm{ppbv}$ (morning), 1.61 to $52.0 \mathrm{ppbv}$ (midday) and 0.5 to $39.9 \mathrm{ppbv}$ (evening). The average ozone levels were increased from morning (14.9 ppbv) to midday (29.3 ppbv) and gradually decreased in the evening period (12.2 ppbv) and peak concentrations were significantly higher in the midday than in the morning and in the evening during all the sampling period. As expected, the general temporal trends in ozone levels and solar radiation were similar. The change in the weather conditions was clearly reflected in the levels of ozone found (Fig. 2). Ozone levels were mainly positively related to radiation variability $(r=0.66$; $\mathrm{P}<0.05)$. Under these atmospheric conditions, the plants of $N$. tabacum showed typical ozoneinduced necroses. A polynomial model of 4 th degree explained the development of leaf necrosis in all groups of plants $(\mathrm{P}<0.05)$, although the smooth of the curve differed among the groups (Fig. 3). The number of days necessary to see the first typical visible symptoms and ranges and averages of ozone levels and meteorological conditions observed during this lag of time are shown in Table 1. The first typical visible symptoms appeared after the $5^{\text {th }}, 6^{\text {th }}$ and $3^{\text {rd }}$ days of exposure respectively in the groups $\mathrm{A}$ to $\mathrm{C}$ of the plants. The highest average levels of ozone and of solar radiation occurred during the initial days of exposure that preceded the appearance of necroses in the plants of group B. On the other hand, the maximum average temperature and the highest relative humidity occurred respectively during the initial period of exposure of groups $\mathrm{A}$ and $\mathrm{C}$ of plants, when foliar symptoms were not still apparent. The maximum \% of leaf area affected by necroses was observed in the first group (A) of plants (20\%; Fig. 3a), a period of exposure in which the ozone was the lowest $(19$ ppbv in average), compared to the observed in the other periods (between $21 \mathrm{ppbv}$ in $3 \mathrm{~B}$ and $26 \mathrm{ppbv}$ in $3 \mathrm{C})$.

\section{DISCUSSION}

The formation of ozone during the experimental period occurred under conditions of strong solar radiation, high temperature and low humidity. Ambient levels of ozone measured in this study were consistent with those found in previous studies reported in certain urbanized sites, such as those observed in United Kingdom (Jekin, 2004). On the other hand these levels were quite lower compared to those measured in Rome by Possanzini et al. (1996) for example. 


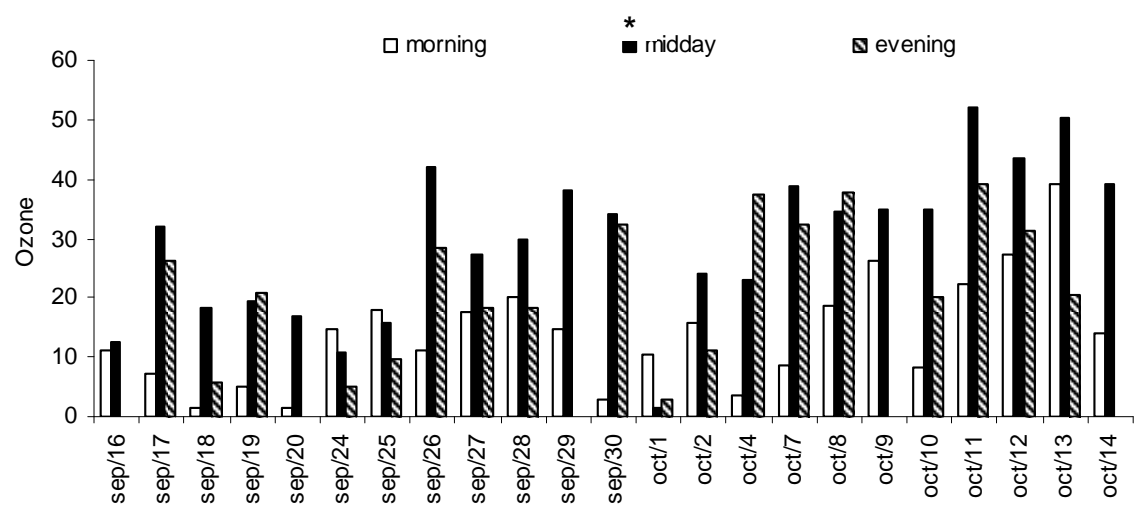

Figure 1 - Mixing ratios of ozone (ppbv) in the morning, midday and evening periods at the exposure site (Institute of Botany, São Paulo, Brazil). * Concentrations significantly higher than those measured in the morning and in the evening $(\mathrm{P}<0.05)$.

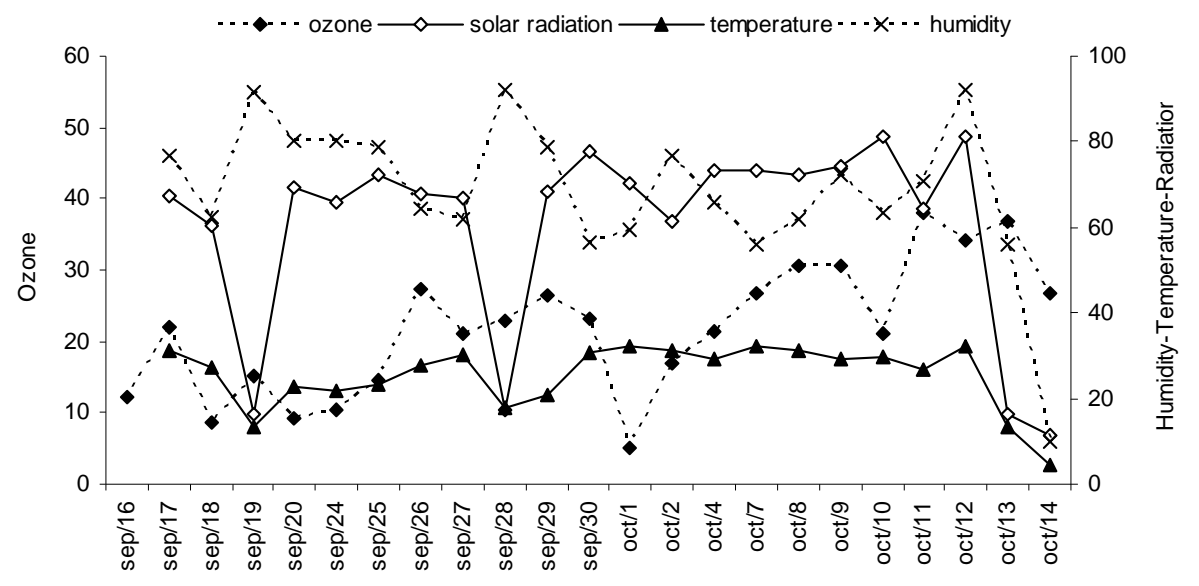

Figure 2 - Daily average of ozone levels (ppbv), temperature $\left({ }^{\circ} \mathrm{C}\right)$, relative humidity $(\%)$ and solar radiation $\left(\mathrm{MJ} / \mathrm{m}^{2}\right)$ during the sampling period at the exposure site (Institute of Botany, São Paulo, Brazil).

In fact, site-to-site variations in ozone levels are mainly due to wide differences in the local sources of oxidants. The dynamic chemistry of ozone and of other secondary photochemical pollutants in the atmosphere of São Paulo is partially attributed to the use of hydrated ethanol and gasohol as motor fuel, which directly reduces the emissions of carbon monoxide and non-methane volatile organic compounds but promotes increases in atmospheric concentrations of nitrogen oxide and aldehyde. Consequently, enhanced levels of $\mathrm{O}_{3}$, PAN, organic acids and other photochemical compounds are expected (Tanner, 1998; Campos et al., 1999; Souza and Carvalho, 2001; Montero, et al., 2002; Muramoto et al., 2003).

In such particular situation, the plants of $N$. tabacum 'Bel-W3' showed not to react closely to daily ozone concentrations, although this cultivar has been highly standardized for assessing the biological risks of this pollutant (Heggestad, 1991; VDI 2000, 2003).

The appearance of the first symptoms seemed not related to the ozone concentrations at the beginning of the exposure (Table 1; Fig. 3a to c). The plants from group B (Fig. 3b), for example, which lasted six days to manifest the first 
symptoms, were not submitted to the lowest concentrations of ozone and neither to highest temperatures and lowest relative humidity before the visualization of necroses (Table 1).

Table 1 - Ranges and average (av) of ozone levels (ppbv), temperature $\left({ }^{\circ} \mathrm{C}\right)$, relative humidity $(\%)$ and solar radiation $\left(\mathrm{MJ} / \mathrm{m}^{2}\right)$ between the first day of exposure and the day before the appearance of the first visual injury (Delay).

\begin{tabular}{cccccc}
\hline $\begin{array}{c}\text { Group of } \\
\text { plants }\end{array}$ & $\begin{array}{c}\text { Delay } \\
(\text { days })\end{array}$ & $\begin{array}{c}\text { Ozone range } \\
(\boldsymbol{a v})\end{array}$ & $\begin{array}{c}\text { Temperature Range } \\
(\boldsymbol{a} \boldsymbol{v})\end{array}$ & $\begin{array}{c}\text { Humidity } \\
\text { range }(\boldsymbol{a v})\end{array}$ & $\begin{array}{c}\text { Solar radiation } \\
\text { range }(\boldsymbol{a v})\end{array}$ \\
\hline $\mathrm{A}$ & 5 & $9.1-21.9(15.8)$ & $13-31(24)$ & $62-83(79)$ & $9.1-40.3(30.5)$ \\
$\mathrm{B}$ & 6 & $10.3-27.3(19.3)$ & $13-23(21)$ & $62-92(79)$ & $9.7-40.3(34.9)$ \\
$\mathrm{C}$ & 3 & $4.9-17.1(10.9)$ & $18-21(21)$ & $56-81(83)$ & $10.3-41.0(25.6)$ \\
\hline
\end{tabular}
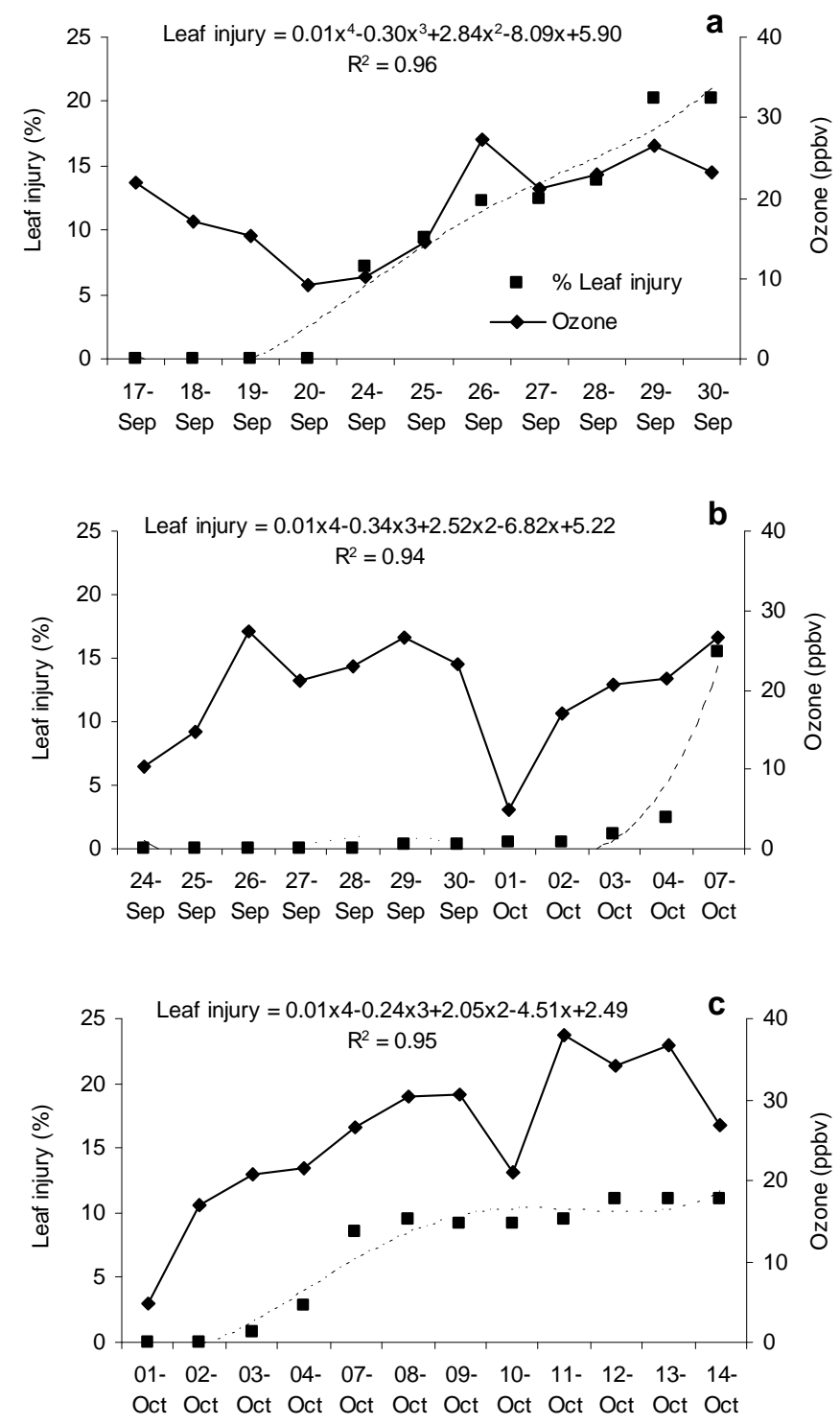

Figure 3 - Daily average of accumulated percentage of leaf area affected by necroses in plants of N. tabacum 'Bel-W3' and ozone levels from September 17th to 30th 2002 - group A (a), September $24^{\text {th }}$ to October 7th 2002 - group B (b) and October 1st to 14th $2002-$ group C (c) at the exposure site (Institute of Botany, São Paulo, Brazil). 
On the other hand, the mean solar radiation during these days was the highest. Indeed, according to Krupa and Manning (1988), environmental factors, such as photoperiod, light intensity, temperature, relative humidity, wind speed, radiation and carbon dioxide concentrations, which may modify the plant sensitivity, are able to interfere on the plant physiology and then on the ozone uptake and appearance of necroses. It is also known that ozone uptake by leaves is mainly governed by atmospheric boundary layer and stomatal conductance. Dry atmosphere and high evaporation usually promote the closure of stomata and reductions in the ozone uptake (Peñuelas et al., 1999; Vergé, 2002; Grünhage, 2003). Davison et al. (2003) emphasize that stomatal conductance is probably the most important control on uptake. In this sense, the stomatal conductance, although not measured, seemed to be restricted by environmental factors in the group $\mathrm{B}$ at the beginning of the exposure, especially by the solar radiation, since the temperature and relative humidity conditions were more favorable to stomata aperture than in the other exposure periods.

The results also indicated that the extent of leaf visible injury was influenced by the plant age or stage of development of leaves, as pointed by Munné-Bosch and Alegre (2002) and Davison et al. (2003). This can be realized by comparing the progress of necroses in leaves of plants from different groups exposed during overlapped periods of time (Fig. 3). The period of September $24^{\text {th }}$ to $30^{\text {th }}$, in which increasing levels of ozone were observed, corresponded to the last and first days of exposure of plants from group A and B (Fig.3 a, b) respectively. During this period, while the leaf area affected by necroses in plants from group A increased closely to the enhancement in ozone concentrations, no leaf necrosis was observed in plants from group B. Besides, the older leaves of plants from group A had been exposed to a previous peak of ozone before this period, which caused some necroses after five days of exposure.

The distinct leaf responses and the delay in the appearance of the first necroses in all groups of plants (Table 1) might be attributed to antioxidants that could avoid cell damage and death caused by reactive oxygen species formed just after the uptake of oxidant pollutants (Bray et al., 2000). The first results obtained in an additional experiment in course indicated that ascorbate concentrations decreased exponentially during the fourteen days of plant exposure, marking characteristically the development of the leaves recommended by VDI (2000) for necrosis evaluation. Besides, the ascorbate levels correlated negatively with percentage of leaf area affected by necroses (M.P. Esposito et al., personal communication). These results indicated that measuring percentage of leaf area affected by necroses only after fourteen days of plant exposure might not be ideal for biomonitoring purposes in São Paulo.

The ozone concentrations on the same day and one day before of necrosis assessment explained respectively only 17 and $34 \%(\mathrm{P}<0.05)$ of the variation in the percentage of leaf area affected by necroses. This meant that other factors influenced the intensity and precocity of short-term leaf responses of N. tabacum 'Bel-W3' exposed in São Paulo. Solar radiation, temperature, other photochemical compounds, among the abiotic factors, as well as plant development and biological protections such as stomatal resistance and antioxidants are the most important variables to be investigated in further long-term field studies and fumigation experiments. After that it would be possible to model the $N$. tabacum 'Bel-W3' responses to the ozone and other oxidant compounds under the regional scale.

\section{ACKNOWLEDGEMENTS}

This work has been partially supported by grants from FAPESP, Fundação do Amparo à Pesquisa do Estado de São Paulo (00/06422-4; 02/04751-6). We thank the Geophysical and Astronomic Institute, University of São Paulo, for providing meteorological data. S.M.R.Sant'Anna thanks FAPESP for the PHD fellowship (02/11956-3).

\section{RESUMO}

$\mathrm{O}$ estudo objetivou verificar se a intensidade e precocidade de respostas foliares de curto prazo de Nicotiana tabacum 'Bel-W3' dependem dos níveis atmosféricos de ozônio e/ou das condições meteorológicas diárias em um Parque Estadual localizado na cidade de São Paulo, SE-Brasil. Entre 16 de setembro e 14 de outubro de 2002, três lotes contendo seis plantas envasadas foram expostos no ambiente por quinze dias. Necroses 
foliares, concentrações atmosféricas de ozônio e parâmetros meteorológicos foram medidos diariamente. A porcentagem média de área foliar com necroses variou de $5 \%$ a $20 \%$. Um modelo polinomial de quarto grau foi proposto para explicar o progresso diário das necroses foliares nas plantas. Os níveis médios de ozônio aumentaram a partir da manhã (1.3-39.2 ppbv) até o meio dia (1.6-52.0 ppbv), diminuindo a tarde (0.5-39.9 ppbv). O padrão diário de aumento de área foliar com necroses não foi relacionado estritamente com ozônio, mas foi influenciado pelas condições meteorológicas e pelo estágio de desenvolvimento das folhas.

\section{REFERENCES}

Bray, R. A.; Bailey-Serres, J. and Weretilnyk, E. (2000), Responses to abiotic stresses. In-Biochemistry and Molecular Biology of Plants, eds. B. B. Buchanan; W. Gruissen and R. L. Jones. American Society of Plant Physiologists (USA), New York, pp. $1158-1203$.

Campos, I. C.; Pimentel, A. S.; Corrêa, S. M. and Arbilla, G. (1999), Simulation of air pollution from mobile source emissions in the city of Rio de Janeiro. Brazilian Journal of Chemical Society, 3, 203-208.

Davison, A. W.; Neufeld, H. S.; Chappelka, A. H.; Wolff, K. and Finkelstein, P. L. (2003), Interpreting spatial variation in ozone symptoms shown by cutleaf cone flower, Rudbeckia laciniata L. Environmental Pollution, 125, 61-70.

Domingos, M.; Bourotte, C.; Klumpp, A.; Klumpp, G. and Forti, M. C. (2002), Impactos da poluição atmosférica sobre remanescentes florestais. InParque Estadual das Fontes do Ipiranga, Unidade de Conservação que Resiste à Urbanização de São Paulo, D. C. Bicudo; M. C. Forti and C. E. M. Bicudo. Secretaria do Meio Ambiente, Governo do Estado de São Paulo, São Paulo, pp. 221-249.

Franzaring, J.; Tonneijck, A. E. G.; Jooijman, A. W. N. and Dueck, T. A. (2000), Growth responses to ozone in plant species from wetlands. Environmental and Experimental Botany, 44, 39-48.

Grünhage, L. and Jäger, H. (2003), From critical levels to critical loads for ozone: a discussion of a new experimental and modeling approach for establishing flux-response relationships for agricultural crops and native plant species. Environmental Pollution, 125, 99-110.

Heggestad, H. E. (1991), Origin of Bel-W3, Bel-C, and Bel-B tobacco varieties and their use as indicators of ozone. Environmental Pollution, 74, 264-291.
Horsman, D. C. (1981), A survey of ozone in Melbourne using tobacco as an indicator plant. Environmental Pollution, 24, 69-77.

Jekin, M. E. (2004), Analysis of source and partitioning of oxidant in the UK-Part 1: the $\mathrm{NO}_{\mathrm{x}}$ dependence of annual mean concentrations of nitrogen dioxide and ozone. Atmospheric Enviroment, 38, 5117-5129.

Klumpp, A.; Ansel, W.; Klumpp, G.; Belluzzo, N.; Calatayud, V.; Chaplin, N.; Garrec, J. P.; Gutsche, H. J.; Hayes, M.; Hentze, H. W.; Kambezidi, H.; Laurent, O.; Peñuelas, J.; Rasmussen, S.; Ribas, A.; Ro-Poulsen, H.; Rossi, S.; Sanz, M. J.; Shang, H.; Sifakis, N. and Vergne, P. (2002), EuroBionet: A Pan-European Biomonitoring Network for Urban Air Quality Assessment. Environmental Science and Pollution Reserch, 9, 199-203.

Klumpp, A.; Klumpp, G. and Domingos, M. (1994), Plants as bioindicadors of air pollution at the Serra do Mar near the industrial complex of Cubatão, Brazil. Environmental Pollution, 85, 109-116.

Krupa, S. V. and Manning, W. J. (1988), Atmospheric ozone: formation and effects on vegetation. Environmental Pollution, 50, 101-137.

Krupa, S. V.; Manning, W. J. and Nosal, M. (1993), Use of tobacco cultivars as biological indicators of ambient ozone pollution: an analysis of exposureresponse relationships. Environmental Pollution, 81, 137-148.

Manning, W. J. and Feder, W. A. (Eds) (1980), Biomonitoring air pollutants with plants. Applied Science Publishers LTD, London.

Montero, L.; Vasconcellos, P. C.; Souza, S. R.; Pires, M. F. A.; Sanches, O. R.; Andrade, M. F. and Carvalho, L.R. (2002), Measurements of atmospheric carboxilyc acids and carbonyl compounds in São Paulo City, Brazil. Environmental Science and Technology 35, 3071-3081.

Munné-Bosch, S. and Alegre, L. (2002), Plant aging increases oxidative stress in cloroplasts. Planta 214, 608-615.

Muramoto, C. A.; Lopes, C. F. F. and Laçava, C. I. V. (2003), Study of tropospheric ozone in São Paulo Metropolitan Region. Paper presented at WMA's 96th Annual Conference and Exhibition, Energy, Economic and Global Challenges, San Diego, EUA.

Orendovici, T.; Skelly, J. M.; Ferdinaldi, J. A.; Savage, J. E.; Sanz, M. J. and Smith, G. C. (2003), Response of native plants of northeastern United States and southern Spain to ozone expousures: determining exposure/response relationships. Environmental Pollution 125, 31-40.

Peñuelas, J.; Ribas, A.; Gimeno, B. S. and Filella, I. (1999), Dependence of ozone biomonitoring on metereological conditions in different sites in Catalonia (NE Spain). Enviromental Monitoring and Assessment 56, 221-224. 
Possanzini, M.; Palo, V.; Petricca, M.; Fratarcangeli, R. and Brocco, D. (1996), Measurements of lower carbonyls in Rome ambient air. Atmospheric Environment 30, 3757-3761.

Saltzman, B. E. (Ed.) (1972), Methods of air sampling and analysis. American Public Health Association on New York, New York.

Sandermann, H. Jr. (2000), Ozone/biotic disease interaction:molecular biomarkers as new experimental tool. Environmental Pollution 108, 337332.

Souza, S. R. and Carvalho, L. R. F. (2001), Seasonal variations in the distribution of formic and acetic acids in the urban atmosphere of São Paulo City, Brazil. Brazilian Journal of Chemical Society 12, 6169.

Souza, S. R.; Vasconcellos, P. C. and Carvalho, L. R. F. (1999), Low molecular weight carboxylic acids in an urban atmosphere: winter measurements in São Paulo City, Brazil. Atmospheric Environment 33, 25632574.

Tanner, R. L.; Miguel, A. H.; Andrade, J. B.; Gaffney, J. S. and Streit, G. E. (1998), Atmospheric chemistry of aldehydes: enhanced peroxyacetyl nitrate foramtion from ethanol-fuled vehicular emissions. Environmental Science and Technology 22, 10261034.

Treshow, M. and Kanderson, X. F. (Eds) (1991), Plant stress from air pollution, John Willy and Sons, New York.
VDI - Verein Deutscher Ingenieure (2000), Biological measuring techniques for the determination and evaluation of effects of air pollutants on plants. Determination of the phytotoxic effects of ozone and other fotooxidants. Standardised exposure of tobacco, VDI 3957/6. VDI/DIN Handbuch Reinhaltung der Luft, Vol. 1a, Beuth-Verl., Berlin.

VDI - Verein Deutscher Ingenieure. (2003), Biological measuring techniques for the determination and evaluation of effects of air pollutants on plants (bioindication). Determination and evaluation of the phytotoxic effects of photooxidants. Method of the standardized tobacco exposure, VDI 3957/6. VDI/DIN Handbuch Reinhaltung der Luft, Vol. 1a, Beuth, Berlin.

Vergé, X.; Chapuis, A. and Delpoux, M. (2002), Bioindicator reliability: the example of Bel W3 tobacco (Nicotiana tabacum L.). Environmental Pollution 85, 337-349. 